\title{
HERMENEUTICS OF SUSTAINABILITY FROM THE PERSPECTIVE OF BRAZILIAN FEDERAL CONSTITUTION
}

\author{
Jeoval Batista da Silva1, Flávio de São Pedro Filho ${ }^{2 \star}$, Ana Carla Pinheiro Freitas ${ }^{3}$, \\ Delson Fernando Barcellos Xavier ${ }^{4}$, and Tiyao Sui-Qui ${ }^{5}$
}

${ }^{1} \mathrm{Ph} . \mathrm{D}$ Student in Constitutional Law at the University of Fortaleza in DINTER by the University Center of Higher Education of Amazonas (CIESA); Member of the Research Group on

Management of Innovation and Technology (GEITEC), and Center for Legal Studies o the Amazon at the Federal University of Rondônia (CEJAM), Brazil. E-mail: jeovalbs@gmail.com

${ }^{2}$ Ph.D. in Business Management by UAA, Paraguay; Ph.D in Administration by USP, Brazil. Post-

Doctor in Management and Economics by UBI, Portugal. Professor and Researcher of the

Graduate Program in Administration of the Federal University of Rondônia. Coordinator of the

Research Group on Management of Innovation and Technology (GEITEC) at the Federal

University of Rondônia, Brazil. E-mail: flavio1954@gmail.com

${ }^{3}$ Ph.D., Professor of the INIFOR Doctorate Course, Fortaleza, Brazil. E-mail:

cpinheirofreitas@yahoo.com.br

${ }^{4}$ Ph.D., Professor and Researcher of the Professional Master's Program in Human Rights and Justice Development (UNIR/EMERON) at the Federal University of Rondônia, Leader of the Center for Legal Studies of the Amazon (CEJAM/UNIR).E-mail: delsonx@globo.com ${ }^{5} \mathrm{Ph} . \mathrm{D}$ Student in Urban Studies at Université du Québec à Montréal (UQÀM), Canada. E-mail: tiyaosui@gmail.com

${ }^{*}$ Corresponding author

\begin{abstract}
Sustainability has turned out to be a complex issue in the scope of Legal Sciences, in proportion as it directly impacts relationships in society, demanding constitutional interpretation from the perspective of subsidizing social conflicts. This imposes direct implications for these relations, such as the issues inherent in city planning. The aim of the present proposal is to promote the hermeneutic discussion of sustainability from the perspective of the Constitution of the Federative Republic of Brazil, focused on the development of cities. The general objective is to hermeneutically interpret sustainability in the context of the Brazilian Constitution as a contribution to city planning; the specific objectives are (1) to address various forms of interpretation of the Federal Constitution; (2) indicate sustainability-orientating mechanisms for city planning in the Federal Constitution; and (3) to hermeneutically interpret sustainability for city planning according to the Federal Constitution. The task is based on Luhmann's Systems Theory, centered on the convergent social demands, considering that the order is to create a state of social tension exposed to normative demands; and also to keep the subsidiary support of the Constitution Theory discussed in Ommati (2016), in order to confirm an orderly and sustainable configuration of cities. We adopt the Content Analysis Method and the procedures required in the preparation of this task. As a result, a hermeneutic interpretation of sustainability for city planning is reached, using constitutional elements. This task contributes to academic knowledge and furthers
\end{abstract}


the cause of the hermeneutics of sustainability in support of city planning.

Keywords: Management. Hermeneutics. Sustainability. Theory of the Constitution. Theory of Systems.

\section{INTRODUCTION}

The Federal Constitution of Brazil is established as a normative system regulating the social system of a community, aligned with all the subsystems that guarantee the maintenance of the structure of the Democratic State, designed to ensure the exercise of social and individual rights, freedom, security, wellbeing, development, equality and justice as the supreme values of a fraternal, pluralistic and unprejudiced society founded on social and committed harmony in its internal and international order.

In the structure of the Federative Republic of Brazil the states, municipalities and federal districts participate in the administrative geography. From them can come new structures, with the permission and criteria defined in the Federal Constitution. Mutations of structures must embrace sustainability in their environmental, social, economic and institutional dimensions.

The changes in the administrative structures of the municipalities constitute city planning, where all the local policies offering guarantees of the competence of the state are realized. In the federal constitution are the devices that regulate the creation and dismantling of the organic laws that govern the local structure, as well as the principles that they must contain.

When constructing new local structures, those who observe the law face the phenomenon of complexity, understood as the totality of possible external events that require the mechanisms of reception and processing of the city planning system to be expanded. This brings planners into the hermeneutics of sustainability in expanding the possibilities of building municipal structures which adhere to the balance of social, environmental, economic and institutional dimensions, obeying the spirit of Article 225 of the Brazil Federal Constitution.

\section{CONCEPTUAL THEORETICAL REFERENCE}

The references are fundamental as a theoretical focus for the object under study because they allow perspectives from which to draw the doctrinal pillars supporting paradigms, as Pedro Filho (2013) discusses. This task follows the recommendation in Siena (2011), whose theoretical framework lies in the field of the proposed approach, in order to provide discussion, analysis and criticism. The basic support is found in Kurt Lewin's Field Theory, on which the treatment is based of the forces that influence decisions involving municipal budget planning. As subsidiaries, Institutional Theory affirms the strategies that surround the force field, and Contingency Theory contributes the elements related to the environment where the budget plans will be elaborated. Other concepts are accepted for interpreting the current state of the art.

\subsection{Constitution}

In the history of mankind, several models of power have been preceded by a discussion of ways to regulate the state. Throughout history, the movements of society have been seeking the most appropriate ways of granting the right of organization to the decision of the majority. The emergence of what has been called Constitutionalism inaugurated new areas of legal knowledge: Constitutional Law, State Theory and Constitution Theory. The historical milestone in the constitutional theme came with the French revolution, which generated the French constituent assembly after the ideas of Emmanuel Joseph Sieyès. It became a subject studied in the academies consolidated only in the Faculty of Paris in 1934, according to the research of Del Negri (2016).

Del Negri (2016) goes on to explain Sieyès' conception that the state is something directed at total power and comprehensively based on the figure of power; this is inconceivable outside of society, because it always manifests itself through social relations. Power in this sense loses the dimension of an unassailable source when it is called upon to confront the democratic pretensions of legality and legitimacy, concluding that the state is an institution that legitimates itself in the Constitution.

Studies in Ommati (2016) suggest that discussion on the concept of the Constitution goes back to Aristotle, as a very broad concept, and refers to the normative set which organizes and configures the social structure 
of a certain community; he states that these norms, religious, economic, political and legal, are moral in nature. Social relations began to take on complexity such as those contained in the context of sustainability from the normative logical principles of the Constitution.

By means of the Constitutions, whether formal or rigid, which form a mechanism for structurally coupling laws and politics, positive law is permitted to become a means of political conformation, so that constitutional law becomes a legal instrument for implanting political discipline, in this sense Constitutions present the functions of creating, conforming and regulating political relations and the limitation of the state.

\subsection{Methods of interpretation of the constitution}

The process of understanding involves universes of experience: the universe of experience in which the text was conceived and the universe of interpreted experience. At present, the interpretation of constitutional norms is a set of methods and principles developed by doctrine and jurisprudence on the basis of different but generally mutually complementary criteria or premises, which only confirms the already signaled unitary character of interpretation as an action. In this context the literature reveals several methods of interpretation: the classical legal or hermeneutical method; the problematic topical method; the hermeneutic concrete method; the spiritual scientific method'; the normative structuring method; and the method of constitutional comparison, as discussed in Coelho (2011).

The legal or hermeneutic-classical method takes the Constitution as law; in this sense it must be interpreted according to the traditional rules of hermeneutics, articulating and complementing itself to reveal its meaning, and ensuring the same elements of interpreting the laws in general. In this method, the task of the interpreter as the one applying the law, is to discover the true meaning of the norm and to be guided by it in its application (Coelho, 2011).

The problematic topical method conceives the constitution as an open system of rules and principles, which means that it requires different interpretations; that a problem is defined as any question that apparently allows more than one answer; and that it can be said that the traditional hermeneutical instruments do not solve the emerging doubts of the concretizing interpretation of the new constitutional model For this reason the problematic topical method is the best way to interpret the constitution. Thus, the juridical interpretation constitutes a practical task in which interpretation entails application. The logic insists that if the constitution is an open, fragmentary and indeterminate system, its effectiveness requires the action of an interpreter/applicator to transform the reading of the constitution into an open process of argumentation, in which all the operators on the Constitution participate with equal legitimacy, as Coelho (2011) notes.

In the hermeneutic-concretizing method, the reading of any normative or constitutional text begins with the comprehension of the interpreter/applicator, who is responsible for providing concrete examples of the norm from a certain point in history, that is, the context in which lies the problem to be solved in the light of the Constitution and without reference to personal criteria of justice. The method finds justification in the hermeneutic discoveries of Gadamer, for whom 'to interpret' always also meant 'to apply'. To apply the law means to conceive the case and the law together in such a way that the law itself becomes concrete. In the end, the sense of something general - of a norm, for example - can be justified and actually determined only in and through being made concrete, as in Coelho (2011) maintains.

The scientific-spiritual method presupposes a certain idea of the Constitution, a concept that is adopted as the foundation and starting point for defining the method of interpreting the Constitution that is considered appropriate. It is based on the idea of the Constitution as an instrument of integration, broad, not only from a formal-juridical point of view, but also from a political and sociological perspective, as an instrument for the regulation of conflicts and, therefore, for the construction and preservation of society as a unit (Coelho, 2011).

Another method that serves interpretation is the normative structuring method. This was formulated and fully developed from the ideas of Martin Heidegger and Hans-George Gadamer, for whom also interpreting entails applying. It is based on the premise that there is a necessary implication for the normative scope from the normative program and for the world from the legal precepts that seek to regulate it. The links is so close that normativity itself, traditionally seen as an essential attribute of legal commands, seems to escape the texts in a search for inordinate support, which would make their normalizing purposes effective, as Coelho (2011) describes. This author citing Friedrich Muller, says that it is not the literal content of a rule that effectively regulates a concrete case, but rather the legislative body; a government body; an official member of a public administrative body; judges and courts, and everyone who prepares, publishes and justifies the ruling in a case. In this way, the concept of sustainability becomes part of the norm (Coelho, 2011).

Among the usual methods of interpretation of the Constitution is the method of constitutional comparison. 
Here the interpretation comes from a comparison made to understand the modern constitutional state in relation to different legal geographies. In this comparison it looks for common or divergent points between two or more national states. The detail of the method comes from the fact that it seems logical to understand, confront and apply different methods of interpretation in order later to compare the different constitutional systems (Coelho, 2011).

Studies in Morales (2011), quoting Saviny, support the view that there are four classical methods of interpretation. The first is the grammatical one, in which the object of interpretation is the words used by the legislator to communicate his thoughts, that is, the language of the law. The second is the logical, in which the decomposition of thought or of logical relations unites their different parts. The third is the history of the rule of law on the subject at the time the standard was published; this determines the mode of action of the law and the change that it brought, clarified by the historical element. Finally, the systematic method concentrates on the intrinsic relationship between institutions and the rules of law within a normative set. Here the legislator, already knowing the norm and the historical fact, seeks to complete the concept by learning from the interpreter how to explain the action of the law on the system and the point in the system where these two co-exist.

\subsection{Methods constitutional hermeneutics}

A study by Ommati (2016) shows that hermeneutics is a broader term and can better convey the relationship between reader and text. The interpretive work is only part of the total of reading and interpreting texts. The work of reading a text not only leads to its interpretation; the moments of interpretation, understanding and application are closely related in a circular and infinite process. The use of the term 'hermeneutics' indicates that the work of interpretation is more than mechanical; it involves a relationship of circularity between understanding, interpretation and application, as well as a relationship of involvement between the text and the reader. In hermeneutics there is no neutral interpretation and no immunity from prejudice.

Inserted in the philosophical field, hermeneutics is an activity that begins when the right models no longer help to understand the object, because it gains in substance what it seems to lose in autonomy. This derives from its philosophical elements, which allow jurists to understand their objects in depth of by replacing commentaries on texts with historically more elaborate constructions, in the conviction that interpretation is the work of thought, which consists in deciphering hidden senses in what lies on the surface, unfolding the levels of signification in literal meaning (Coelho, 2011).

Del Negri (2016) echoes this view; for him, the term 'Constitution' always implies constitutional interpretation (hermeneutics). The writer adds that the arguments and grounds in this thematic area have been the object of some research and that the difficulty of interpretation puts the Constitution into a place of important reflection.

The hermeneutic circle following hermeneutic treatment, according to Vesting (2015), together with the need inscribed in the pre-comprehension reflection, is concerned with the process of socializing jurists with one another, while the ordering of the law to represent the normative will goes without question. The author goes on to cite Esser, who cuts into the problem of interpreting the law much more drastically by taking into account the problem situated at the center of hermeneutics: the temporality of all understanding. For him, the information that the interpreter needs for the solution of a case cannot be extracted from the general law in any conclusive way - decision-making always depends on its temporal and objective context.

\subsection{Theory of the constitution in Ommati}

Ommati (2016) and Carl Schmitt, who initiates the thematic in a work entitled 'Theory of the Constitution', modify the location of the study of the Theory of the State: after the Constitution of Weimar, this needed to be systematized. Until then studies on the Constitution had adopted the approach and the context of State Theory: the rupture comes when autonomy is granted to the Theory of the Constitution. After World War II, Constitution Theory initially sought to understand the various constitutional systems around the world. Only after 1964, with the studies on Philosophy of the Language initiated by Hans-Georg Gadamer and Ludwig Wittgenstein, and the publications of Ronald Dworkin, did the Theory of the Constitution seek to be the interpretative key of all rights, including Constitutional Rights.

At this point we should distinguish State Theory from Constitution Theory. The purpose of the present study is to analyze the juridical-social institutionalization of political power, where the central discussion is the figure of the State itself, implying therefore that the State is the organization that comprehends the whole of society. In this scenario the state reveals itself as a privatize organization which must democratize and pluralize the spaces for discussing and constructing the law itself. Constitution Theory includes studies on the law as a whole, welcoming even the discussion of so-called diffuse rights. It comes to problematize all 
social issues, presenting itself as a fundamental and problematizing knowledge of all law and Constitutional Law, according to studies by Ommati (2016). Here the theme of city planning with sustainability is one of the problematizing variables discussed in the life of the Constitution Theory.

Constitution Theory sets out to discuss the main categories of Law, and Constitutional Law, showing the complementary relationship between ideal and experience; that the Constitution is not only a note of good intentions, its texts not only ideal, but produced by human beings. In fact, any legal text can be disregarded, and the community should be concerned with the application and effectiveness of the Constitutional Text (Ommati, 2016).

\subsection{Theory of Systems in Luhman}

Studies in Kaufmann and Hassamer (2015) refer to the Theory of Systems advocated by Niklas Luhmann, in which a social system relating to the meaning of social actions is constituted by the differences between interior and exterior. The functional reference point can be occupied only by something which, in itself, has no exterior, that is, by the world; since this has no threat to its existence, the problem is not its existence but its complexity. Even if the concept of the world is not clear, the problem of complexity can be understood only in the light of anthropological presuppositions. This is the starting point of Luhmann's Systems Theory: the reduced reception and processing capacity of organic systems.

Complexity, understood as the totality of possible events in the world, must be reduced to a measure that allows human life and action to be understood and guided; this (reduction) is achieved by the construction of meanings or systems, that is, by the selection and definition of boundaries between interior and exterior. Such a reduction depends on information about the system and the environment. From the complexity arise two transformations: the first is the expectation of behavior by modifying the legal form and the second is the institution of processes aimed at the elaboration of mandatory collective decisions, making actions on rights a program of decision. The restructuring of the program of decisions makes the law a positivizing force, because in this system the facts and consequences are conditional, with the relationship of "if ... then". In this context, if certain conditions are met, a decision is straightforward; that is, one depends on the other, as applied by the operator of the right. Nevertheless, the choice of consequences is constructed by legislators who do not follow conditional programs but are guided by objectives, such as guarantees of the informational autonomy of citizens, as discussed by Kaufmann and Hassemer (2015).

The activity of reducing complexities is consolidated with the activity of the law applicator, differentiating problems and analyzing points of view, behavior and the expectations of behavior and control; these make law a social system, the solution to which autonomously seeks acceptable alternatives and relates to absorbing complexity - sustainability, in the present case - because the complexity of a system has to be correlated with the complexity of its context. This fact suggests that the legal norms have to be both more abstract and indefinite and more complex if the complexity has to be overcome within the system (Kaufmann and Hassemer, 2015).

\section{APPLIED METHODOLOGY}

In Creswell (2010) one of the tasks of a literature review is to determine which theories can be used to explore the issues in an academic study. It appears at the beginning of the research and provides a lens for defining what is to be observed and which questions addressed. Scientific methodology studies the investigation procedures of the phenomenon and this process facilitates their identification. Identifying the phenomenon must precede its dismantling, that is, analyzing its content, as proposed in this task.

For Oliveira (2008), the Content Analysis Method is a scientific research tool with multiple applications. In this typology the researcher is faced with the work philosophy, the research strategy and the research method.

As Denzin (2010) comments, all research has the intention of elaborating knowledge to allow the understanding and transformation of experience. Reflexivity and textual representations must be addressed under the participatory or cooperative paradigm, essentially in the context of critical theory as it appears here at one remove. Thus, it explores the meaning of sustainability, through the Theory of Systems in Luhmann and Theory of the Constitution in Ommati (2016), operating a hermeneutic analysis of the country's federal constitution in the field of law.

\subsection{The method and procedures adopted}

This task was elaborated through the Content Analysis Method, which aims to obtain inferences through the objective and systematic identification of specific characteristics of the message. This practical inference is oriented in the context of the facts, as recommended in Creswell (2010). The procedures used may vary 
according to the objectives of the research; however, whatever its purposes, it must, to have scientific value, submit to some precise rules that differentiate it from purely intuitive analysis. As a first step, the task demanded a search of literature, as indicated by Oliveira (2008); then data and the elements of sustainability of the Brazilian Federal Constitution were extracted for analysis and criticism, as is common in the investigative process of a qualitative nature of a given content.

\section{HERMENEUTICS OF SUSTAINABILITY UNDER THE OPINION OF THE FEDERAL CONSTITUTION}

The results in the proposed analysis of the hermeneutics of sustainability contained in the Brazil Federal Constitution of 1988 are shown below. The specific objectives are treated in the light of the theoreticalconceptual content raised and the critical point will be constituted with a view to extracting elements of theories from the literature. Next comes a analysis of the hermeneutics of sustainability in face of elements from the Federal Constitution, with support from the Theory of Constitution and Systems Theory, as well as a critique of the cognitive line of approach.

\subsection{Approach to forms of interpretation of the Brazilian Federal Constitution}

The study of the theoretical base indicates a framework of theoretical application that contributes to solving the problem of sustainability; this is the element to be taken to the center of the discussion so as to highlight the scenario of the decisions in accordance with the time and space of society at this point in its historicity, according to the following table.

Table 1: Theoretical conceptual elements

\begin{tabular}{|l|l|}
\hline Theoretical basis & \multicolumn{1}{|c|}{ Concept of the application in the municipal budget system } \\
\hline 1. Constitution & $\begin{array}{l}\text { 1.1 This is a set of norms that organizes and configures the social structure of a certain } \\
\text { community, including moral, religious, economic, political and juridical norms, as well as } \\
\text { complex social relations outside the context of sustainability. }\end{array}$ \\
\hline $\begin{array}{l}2.1 \text { This touches on the law as a whole, reaching the discussion of even the so-called } \\
\text { Theory }\end{array}$ & $\begin{array}{l}2.1 \text { The } \\
\text { diffuse rights; it problematizes the social issues, presenting itself as a fundamental and } \\
\text { problematizing knowledge of all rights and the Constitutional Right. }\end{array}$ \\
\hline $\begin{array}{l}\text { 3. Theory of } \\
\text { Systems }\end{array}$ & $\begin{array}{l}3.1 \text { Law is a social system that is constituted by the complexities contained in the } \\
\text { differences between interior and exterior, and should be reduced by the selection and } \\
\text { definition of boundaries between the interior and exterior, from restructuring with the } \\
\text { positivity of law. }\end{array}$ \\
\hline
\end{tabular}

Source: Elaborated by the authors.

The concepts raised in support of the theoretical set require its applicability to operational procedures for solving the problem raised in this task are presented in the following table.

Table 2: Conceptual instrument of the theoretical operational application.

\begin{tabular}{|l|l|}
\hline \multicolumn{1}{|c|}{ Theoretical basis } & \multicolumn{1}{|c|}{ Concept of the application in the municipal budget system } \\
\hline & $\begin{array}{l}1.1 \text { The legal or hermeneutic-classical method: the Constitution is law and must be } \\
\text { interpreted according to the traditional rules of hermeneutics. } \\
1.2 \text { Topical-problematic method: here the Constitution is an open system of rules } \\
\text { and principles. } \\
1.3 \text { Hermeneutic-concretizing method: here it is the pre-understanding of the } \\
\text { interpreter/applicator that concretizes the norm derived from the historicity of } \\
\text { society. } \\
1.4 \text { Scientific-spiritual method: this has an idea as a basis for defining the method } \\
\text { which it considers appropriate to the interpretation of the Constitution. } \\
1.5 \text { In the normative structuring method, interpret = apply. } \\
1.6 \text { The method of constitutional comparison: this stems from the comparison of } \\
\text { common or divergent points in order to understand the modern state. }\end{array}$ \\
\hline 1. Interpretation & $\begin{array}{l}2.1 \text { Circular and infinite process, involving understanding, interpretation and } \\
\text { application, in addition to a relationship of involvement between the text and the } \\
\text { reader. }\end{array}$ \\
\hline 2. Hermeneutic &
\end{tabular}

Source: Elaborated by the authors.

It is necessary to visualize the system scenario where the actors are represented synthetically by legal operators such as judges, lawyers, public opinion and citizens, and managers, given the results of decisions 
that modify the dynamics of cities, when (decisions) reach operationality, for example on the width of streets to provide environmental, social, economic, and even institutional adequacy. This is illustrated in the diagram below, which visually presents the operational moments that need a hermeneutic analysis of sustainability as a way of solving the social demands.

Fig. 1: Operational construction of the hermeneutics of sustainability

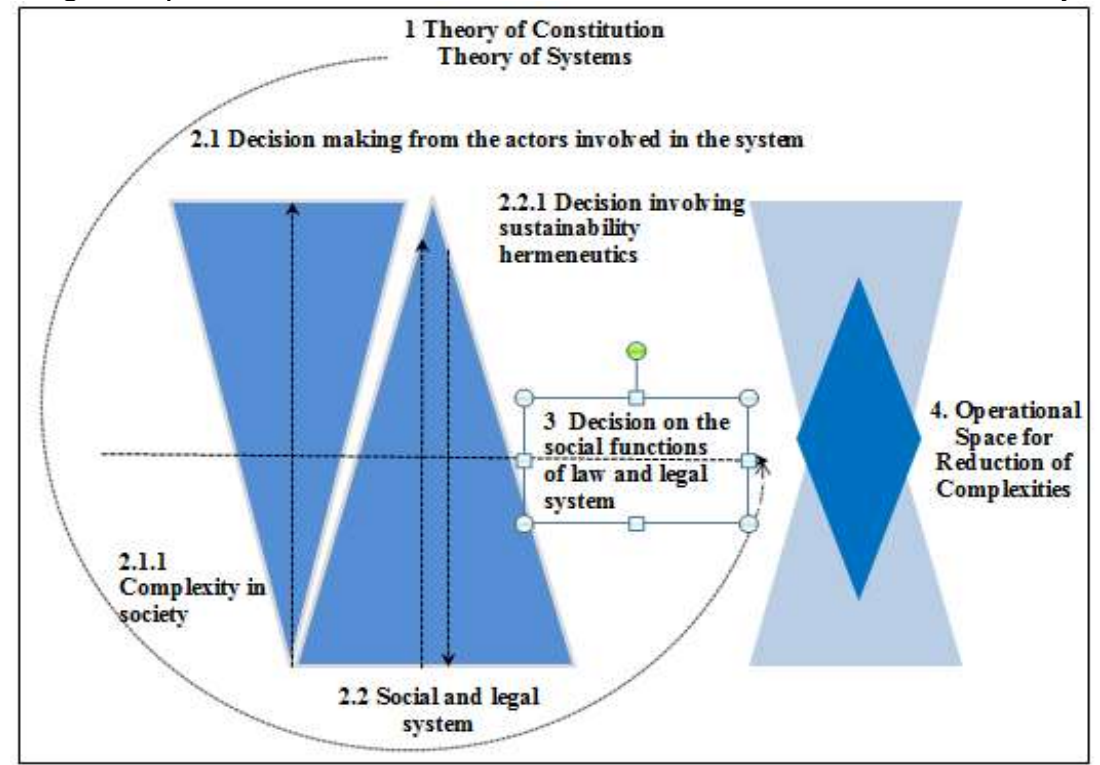

Source: adapted by the authors on the basis of theory

To interpret the diagram above, the phases of the social system with its complexities are systematized in Table 3 below. It can serve as an instrument in the constitution of the scenario, where the issues related to the hermeneutics of sustainability in the procedures proposed in this task are tackled.

Table 3: Elaboration of the hermeneutic diagram of sustainability specifications

\begin{tabular}{|c|c|}
\hline Specification & Indication \\
\hline 1. Theories & $\begin{array}{l}\text { 1.1 The Theory of the Constitution is applied to the social system by } \\
\text { representing the structuring normative set of a community comprising the } \\
\text { moral, religious, economic, political and legal issues that typify complexities. } \\
1.2 \text { The Theory of Systems finds a field for solving the problem in the present } \\
\text { research; it consists in conceiving the Constitutional Law as part of the social } \\
\text { system, supporting the solutions that entail complexity, such as sustainability. }\end{array}$ \\
\hline 2. Decision Making & $\begin{array}{l}\text { 2.1 Reduced capacity to receive and process possible events in the world, by } \\
\text { the actors of the social system. Sustainability here is considered to mean } \\
\text { understanding the preference for electric vehicles in mobility in cities. }\end{array}$ \\
\hline 3. Complexities in society & $\begin{array}{l}\text { 3.1 Reduced capacity to receive and process possible events in the world, by } \\
\text { the actors of the social system, considered sustainability here as } \\
\text { understanding the preference for electric vehicles in mobility in cities. }\end{array}$ \\
\hline 4. Social and legal system & $\begin{array}{l}\text { 4.1 Normative system based on the values directing the actions of the } \\
\text { elements of society. }\end{array}$ \\
\hline $\begin{array}{l}\text { 1. Decision of the social } \\
\text { functions of the law and legal } \\
\text { system }\end{array}$ & $\begin{array}{l}\text { 5.1 Decisions contained in the actions of structuring the society as } \\
\text { administrative, and the decisions on social issues emanating from the State } \\
\text { through its organs. }\end{array}$ \\
\hline $\begin{array}{l}\text { 6. Decision involving the } \\
\text { hermeneutics of sustainability }\end{array}$ & $\begin{array}{l}\text { 6.1 Composite decision of activities comprising interpretation, understanding } \\
\text { and application related in a circular and infinite process, in a process of the } \\
\text { historicity of society }\end{array}$ \\
\hline $\begin{array}{l}\text { 7. Operational space to reduce } \\
\text { complexities }\end{array}$ & $\begin{array}{l}\text { 7.1 The reduction of complexities in the field of sustainability results from the } \\
\text { hermeneutics of sustainability aligned with constitutional precepts, } \\
\text { consolidating the normative system of social values. }\end{array}$ \\
\hline
\end{tabular}

Source: Elaborated by the authors 
The solutions originated both at the administrative level and resulting from judicial decisions for city planning require the perception and mental processing of a set of elements derived from the current norms, to guarantee the maintenance of the state. It is relevant to note that Constitution Theory comprises a normative structuring in all the founding dimensions of a society, such as those related to moral, religious, economic, political and juridical norms; it is noted also that, with reference to this Theory, founders should observe the structuring rule when making a decision that favors the perpetuation of the state organization.

A founding and structuring set of a society seeks a mechanism that establishes the closed processes of reaching a solution, since the result of any processing is necessarily guided by the set of norms, and of course reaches the result orientated to the Brazil Federal Constitution. Systems Theory conceives as a system the constitutional normative set, revealing that norm, praxis and decision follow one another in a circle. Decisions are always required when the complexity arising from social everyday life is manifested. Therefore, it can be inferred that all the demands that are made on the administrative and judicial processes are complex, representing the reduced capacity of perception and processing of the systems of a particular group or community. This complexity is present in all issues involving sustainability, such as the Kyoto Protocol, which has Brazil as one of its signatories and requires a diversity of measures with social impact that cannot be delivered on the basis of popular perception alone but demand scientific knowledge to cope with the natural complexity of the paradigm.

The social actors, in all the extracts, are constantly presented with the need to make decisions involving sustainability. Notably, the managers of social and legal systems face questions about city planning, such as the authorization of subdivisions in areas subject to reforestation, environmental compensation, urban routes and urban modeling, the size of urban lots All these issues must fit in to the Constitutional system. However, a hermeneutic path of sustainability is needed in decisions focused on the Federal Constitution. This is imposed not only by a simple reading of the infra-constitutional standard and the requirements mentioned in the forms required for the licenses; it is also required of anyone who decides the question in analyses involving mainly adherence to the paradigm of article 225 of the Brazil Federal Constitution, which shows the content and level of complexity in each case.

The complexities consist in a reduced ability to receive and process possible events in the world. They thus designate all the occasions when society, whether in a group or individually as citizens, finds it hard to decide on a certain issue in accordance with constitutional norms. Often society is faced with a challenge involving a question of sustainability that does not accept the binary "yes" or "no" model, one requiring a decision at the intersection of the environmental, social, economic and institutional dimensions appropriate to a constitutional system. Only in the life of the hermeneutics of sustainability does the decision reach an ideal point. It is with such issues that the decision on, say, the route of a road that demands the indemnification of constructions and the suppression of vegetation is found to offer a better distribution of traffic flow in a city. The economic viability of the enterprise is not merely at stake; rather the situation itself is integrated in time and space, and it is only possible to attain it through analyzing the hermeneutics of sustainability within the legal and social system.

The norms of the social and legal systems are directly based on values and guide the actions of members of society whose purpose is to control through principles in an operative way the decisions about the complexities that arise in the system. Every decision is a form of communication, since it confirms the preestablished values in the constitutional structure and legitimates the existence of the state. In this sense, judicial verdicts are decisions of last analysis in the social and juridical system, when establishing relations of adequacy of the fact with the constitutive premises of the State. Sustainability issues do not go beyond these decisions; they are immanent to social praxis and depend on the validation of the decisions through the acceptance of and compliance with the principles established in the Federal Constitution. The decision deriving from the hermeneutics of sustainability reaches all the validating elements in the social environment and preserves the uniqueness of the State.

The decisions are contained in the actions of the structuring society on all issues involving complexity, when they confirm the constitutive normative grounds of the state. These decisions, to have legitimacy, must be composed of activities that comprise the cycle of interpretation, understanding and application. This cycle looks for ways to resolve complexity in the historical process Historicity consists of reaching a possible point within the scenario proposed in the constitutional subjective norm.

The moment in which the elements of the system are somehow received and processed reduces the complexity of the problem faced. This moment will only be reached synchronously with the founding elements of constitutional structure by means of hermeneutics, consolidating the normative system of social values. Town planning issues, such as generic real estate development plans, the establishment of permanent preservation areas and public facilities, and forestation planning, are necessarily inserted in the 
field of complexities with the validation of the hermeneutics of sustainability underpinning the decision of agreement with the Brazil Federal Constitution.

\subsection{Indication of sustainability guiding devices}

The study of the theoretical base indicates a framework of theoretical application that contributes to solving the problem of sustainability; this is the element to be taken to the center of the discussion so as to highlight the scenario of the decisions in accordance with the time and space of society at this point in its historicity, according to the following table.

The constitutional mechanisms considered in this topic are about sustainability and are necessary for city planning. As already outlined in the theoretical conceptual framework, the Brazil Federal Constitution is a set of norms that organizes and configures the social structure of a given community, containing moral, religious, economic, political and juridical norms, together with the complexities in social relations such as those contained in the context of sustainability. In this perspective of organizing society the guiding directives of the normative bases of urban organization are inserted to support the resolutions of the complexities of this field.

The Federative Republic of Brazil is formed by the indissoluble union of the states, municipalities, and federal districts, establishing an administrative geography. In certain cases it sometimes requests judgment on the meaning and system described in Article 29, which establishes the regulating instrument of the municipal system, predicting popular initiatives of concern to cities. Here it intersects with theoretical support, since it demands decision-makers' attention to the hermeneutics of sustainability in reducing the complexity contained in the context of city planning. Among the complexities that require city planning solutions is sustainability, which is configured in Article 225 of the Federal Constitution, from which derive a diversity of normative legal subsystems. The following table lists the guiding mechanisms of sustainability for city planning contained in the Constitution.

Table 4: Constitutional mechanisms guiding sustainability in city planning.

\begin{tabular}{|c|c|}
\hline $\begin{array}{l}\text { Constitutional } \\
\text { mechanism }\end{array}$ & Content \\
\hline 1. Article 18 & $\begin{array}{l}\text { Art. 18. The political-administrative organization of the Federative Republic of Brazil } \\
\text { comprises the Union, the States, the Federal Districts and the Municipalities, all } \\
\text { autonomous, under the terms of this Constitution. } \\
\ldots \\
\S 4^{\circ} \text {. The creation, incorporation, fusion and dismemberment of Municipalities will be made } \\
\text { by state law, within the period determined by Federal Complementary Law, and will depend } \\
\text { on prior consultation, through plebiscite, with the populations of the municipalities involved, } \\
\text { after disclosures by the Municipal Feasibility Studies, presented and published in the form } \\
\text { of laws. }\end{array}$ \\
\hline 2. Article 28 & $\begin{array}{l}\text { Art. 28. The Municipality shall be governed by an organic law, voted in two shifts, with a } \\
\text { minimum interval of ten days, and approved by two-thirds of the members of the Municipal } \\
\text { Council, which shall promulgate it, in compliance with the principles established in this } \\
\text { Constitution, in the Constitution of the respective State and the following precepts. }\end{array}$ \\
\hline 3. Article 182 & $\begin{array}{l}\text { Art. 182. The urban development policy, implemented by the municipal government, } \\
\text { according to general guidelines established by law, aims to order the full development of } \\
\text { the social functions of the city and ensure the well-being of its inhabitants. }\end{array}$ \\
\hline 4. Article 183 & $\begin{array}{l}\text { Art. 183. The person who possesses as his urban area up to two hundred and fifty square } \\
\text { meters of land, for five years, uninterruptedly and unopposed, using it for his dwelling or his } \\
\text { family, will acquire the domain to himself, if he does not own any other urban or rural } \\
\text { property. }\end{array}$ \\
\hline 5. Article 225 & $\begin{array}{l}\text { Art. 225. Everyone has the right to an ecologically balanced environment, a common good } \\
\text { used by the people and essential to a healthy quality of life, imposing on the Government } \\
\text { and the community the duty to defend and preserve it for present and future generations. }\end{array}$ \\
\hline
\end{tabular}

Source: Elaborated by the authors.

\subsection{Hermeneutic interpretation of sustainability for city planning}

City planning must theoretically converge on the provisions of the current Constitution, requiring interpretation in support of those involved in this arduous task, such as mayors, community leaders and other actors committed to the approach. The hermeneutics treated in this study may allow such 
interpretation, understanding and application in this circular and infinite process. Special moments of reflection will involve the text and reader comprehensively in the surroundings of the task of mechanically interpreting the normative text. The actors located in the social system must be endowed with the cognitive capacity that reduces flaws in the rights models in the understanding of the object.

Sustainability in the field of social, economic, environmental and institutional dimensions should be a decisive element in city planning procedures. In this field is an element of complexity, demanding adherence to hermeneutics for a better understanding of the system, when the actors' capacity to receive and process is reduced. It would be simple to read the constitutional text in isolation. However, planning requires a broad scope of interpretation, understanding and application, including the elements of sustainability.

A flat analysis of Article 18 of the Brazil Federal Constitution would imply its absolute autonomy, but this autonomy has a limitation between the interior and the exterior of the constitutional system, which must exercise the interpretation, understanding and application of the mechanism. Adhesion to the sustainability element should also play a part in composing the variables taken to the analysis; if not, this will be the process that widens the differences between internal and external, as well as demonstrating a reduced capacity for reception and processing on the part of the operator In city planning in practice.

The creation, incorporation, fusion or dismantling may be only in the eyes of the judicial operator, awaiting only a written document with reasons for any of the possibilities authorized there. In the preparation of the documents which will be decision in city planning, literal interpretation cannot be considered valid, since it does not evince the hermeneutic process containing the sustainability element, since this is inserted in the constitutional system. These possibilities are limited, first in the Federal Constitution itself, and then in the normative subsystem that should be determine the field of sustainability, and the analysis should consider these elements in the act of decision.

The subjection of the Municipality to an Organic Law in Brazil, likewise, does not find absolute liberality. Sustainability is configured as a complexity meriting analysis in order to support the maintenance guidelines of the constitutional order. In this context, hermeneutics finds a deep field to subsidize the operators in the construction of the order, as regards the feasibility of the actions aiming to balance the constituent elements of the environmental, economic, social and institutional dimensions. Thus, for exemple, an Organic Law that set forth the treatment of solid waste without establishing the environmental mechanism for this dimension would be in conflict with the constitutional system, specifically Article 225 of the Brazil Federal Constitution.

With regard to the full development of social functions, sustainability is plotted throughout the analysis of hermeneutics. The context of the development of sustainability is in disagreement with the national order. In the same way, the acquisition of property by an adverse possession institution must be welcomed in the field of complexities, so as to sift hermeneutics and allow a decision that is oriented towards the maintenance of constitutional order.

\section{CONCLUSION}

City planning, given the need to expand the reception and processing of the system by social actors, must conform to the guidelines set forth in the Federal Constitution, being relevant to the analysis of the devices contained in the systematized form to show the support of hermeneutics and reach the elements of sustainability.

Hermeneutics is based on pre-comprehension which reveals it as a driver originated in the praxis of society's everyday life. It is desirable because of the evolution of the complexities in the social system, for it is necessary to broaden the reception and understanding of the social system through a procedure that succeeds in interpreting, understanding and applying the norms. It enables planners to analyze the founding values of a society with the support of the elements of sustainability considered in the environmental, economic, social and institutional dimensions.

City planning is contained in a system with complexities drawn from the Brazil Federal Constitution, under the aegis of the construction of local regulations, until the administrative activity is defined as an entity. In the context, its creation is filtered through the hermeneutics of sustainability to demonstrate the viability and validity of the procedure when confronted with the requirement to disclose sustainability for the creation, operationalization and permanence of the entity in the Brazilian Constitutional System.

If it is assumed that the planning of the constitutional system is necessary in urban planning, and that sustainability is revealed as a herald of complexity in the social system, requiring hermeneutics to support the expansion of the social system's capacity to receive and process of the intentions for planning, it is appropriate to include hermeneutics in the city planning scenery. 


\section{ACKNOWLEDGEMENT}

Thank the University of Beira Interior, Faculty of Social and Human Sciences, Department of Management and Economics, Post-Doctoral Programme in Management and Economics, focused on Management Strategy for Innovation and Sustainability, Covilhã, Portugal.

Website: http://www.ubi.pt/Entidade/Ciencias_Sociais_e_Humanas

\section{REFERENCE LIST}

Brasil. Constituição (1988). Constituição da República Federativa do Brasil. Brasília, DF: Senado Federal: Centro Gráfico.

Coelho, Inocêncio Mártires. (2011). Interpretação Constitucional. São Paulo: Saraiva.

Creswell, John W. (2010). Projeto de Pesquisa: métodos qualitativo, quantitativo e misto. Porto Alegre: Artmed.

Del Negri, André. (2016). Teoria da Constituição e Direito Constitucional. Belo Horizonte: Editora Del Rey.

Denzin, Norman K. (2006). O planejamento da pesquisa qualitativa: teorias e abordagens. Porto Alegre: Artmed.

Kaufmann, Arthur; Hassamer, Winfried. (2015). Introdução à Filosofia do Direito e à Teoria do Direito Contemporâneas. Lisboa: Fundação Calouste Gulbenkian.

Morales, Cesar Mecchi. (2011). Originalidade e interpretação constitucional. PhD Thesis. 283 pags. São Paulo: Universidade de São Paulo.

Oliveira, Denize Cristina de. (2008). Análise de Conteúdo Temático-Categorial: Uma proposta de sistematização. Revista de Enfermagem da UERJ. Rio de Janeiro: UERJ.

Ommati, José Emílio Medauar. (2016). Teoria da Constituição. Rio de Janeiro: Lumen Juris.

Pedro Filho, Flávio de São. (2013). Paradigmas e perspectivas estratégicas para o ecoturismo indígena em Rondônia, Brasil. Caderno Virtual de Turismo. Rio de Janeiro, v. 13, n. 2, pp.227-252, Aug. 2013.

Siena, Osmar. (2011). Metodologia da pesquisa científica: elementos para elaboração e apresentação de trabalhos acadêmicos. Porto Velho: PPGMAD/UNIR.

Silva, Cristiane Rocha, et al. (2005). O uso da análise de conteúdo como uma ferramenta para a pesquisa qualitativa: descrição e aplicação do método. Organizações rurais agroindustriais. Lavras: UFLA.

Vesting, Thomas. (2015). Teoria do Direito: uma introdução. São Paulo: Saraiva. 